\title{
Automated Mobile Telecom Cell Sites System
}

\author{
Ehigiator Iyobor Egho-Promise and Bamidele Ola
}

\begin{abstract}
Telecommunication is the transmission of traffic from one place to another in a network through a media using mobile station. Cell site is referred to as the base station of telecommunication, it is part of telecom network that allow subscribers to access services from the telecom service providers.

Cell sites depend on core network and transmission system to function, it is not a standalone network. It is the interface between mobile station and the network (core network and transmission system).

In this research, an automated mobile telecom cell site system will be designed and developed. The system will help to provide accurate and reliable online information about cell sites equipment and determine profit or loss from cell sites.

Qualitative research approach will be used in the study while interview will be employed to collect data.
\end{abstract}

Index Terms - Cell sites, base station, network, telecom.

\section{INTRODUCTION}

Telecom cell sites otherwise call base station serves as interface between mobile station and the network. In $2 \mathrm{G}$ network, it is called Base Transceiver (BTS), it is known as NodeB in 3G network, it is called evolved node B (eNodeB) in $4 \mathrm{G}$ network while in 5G network, it is called GNodeB.

Telecommunication is simply the transmitting and receiving of voice or data on telephone via communication media [1].

Telecommunication is made up of the followings:

- Core network. It preforms switching of traffic from the caller to the called party

- Access network: it enables subscribers to access the network services and the cell site is part of the access network that provide services directly to the subscribers,

- Transmission system: it is the media which convey the traffic. The media could be Very Small Aperture Termina (VSAT), fiber cable, digital microwave radio, etc.

\section{A. Problem Statement}

The manual system of processing and storing cell sites data in spreadsheet causes inefficiency, inaccurate information and delay in decision making.

\section{B. Objectives of the study}

1. To provide accurate and reliable online information about cell site equipment.

2. To determine profit or loss from cell sites.

\section{Significance}

The automated mobile telecom cell site system will help to provide efficient and accurate online information of equipment status at cell sites and determine profit or loss from each cell sites.

\section{Scope of the study}

The system will only provide status of equipment and profit or loss from cell sites.

\section{LITERATURE REVIEW}

Different literatures were reviewed to ascertain challenges or discover exiting problems relating to cell sites.

\section{A. Types of cell sites}

- Mobile cell site: it is a portable cell site installed on a vehicle to transmit and receive signals/ traffic. It is often used in an event centers to serve temporary purpose.

- Fixed cell site: it is installed in a specific location to transmit and receive signals/traffic.

\section{B. Features of Cell site}

The followings are the characteristics of any telecom mobile cell sites:

- indoor or outdoor site

- transit, hub, backbone, terminal or BSC/RNC/LTE site

\section{Equipment at cell site}

Mobile telecom cell site could have all or some of the below equipment to transmit or receive signals/ traffic.

- Digital microwave radio (indoor and outdoor unit)

- Digital microwave antenna

- IF/RF cables

- Feeder cables

- Mobile cell tower/mast

- Antenna (2G, 3G, 4G or 5G)

- Rectifier cabinet

- Cabinet (for 2G, 3G, 3G or 5G equipment)

- Power distribution board

- IP55 stand

- IP55 panel for power switchover

- Generator as standby power source

- Fuel tank

- Generator

- Air condition unit for indoor cell site

- Shelter 
- Fire extinguisher

- ADM

- DWDM.

Telecom operators use spreadsheet in processing and storing cell sites data and as well as computing profit or loss from cell sites. This manual system is inefficient and the information is not accessible online for quick decision making.

This research will close this gap by designing and developing a web-based system that provide accurate, efficient and reliable status or states of equipment at cell sites and determine profit or loss from each sites.

The use of technology helps in easing exchange of information [2].

\section{Methodology}

Qualitative research will be employed in the research because of its flexibility and the research method tool to be utilized in collecting data is interview because it permits attention to details in collecting data [3].

\section{A. Agile Model}

The automated mobile telecom cell site will be developed using agile model because of its ability to adopt to changes and scalability [4].

The Fig. 1 below illustrates the different phases of agile model.

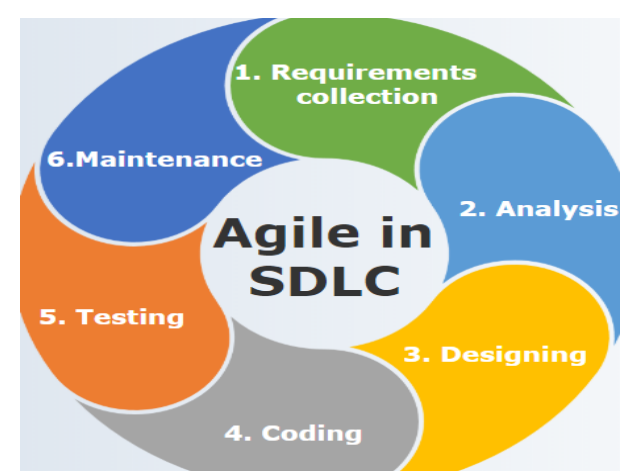

Fig. 1. Agile model.

\section{B. Use case diagram}

It shows relationship between users and the system as shown in the Fig. 2 below.

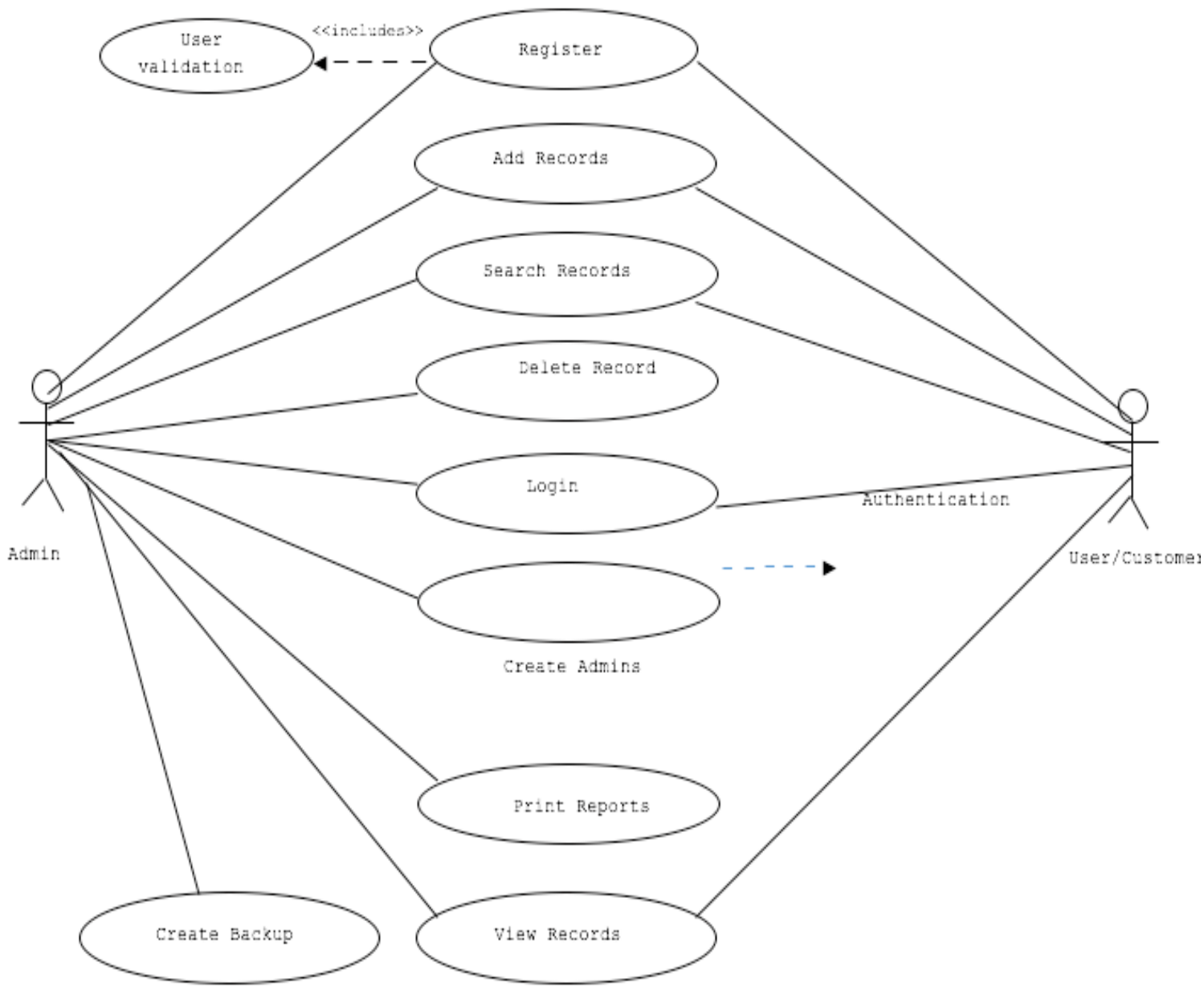

Fig. 2. Use case diagram 


\section{Flowchart diagram}

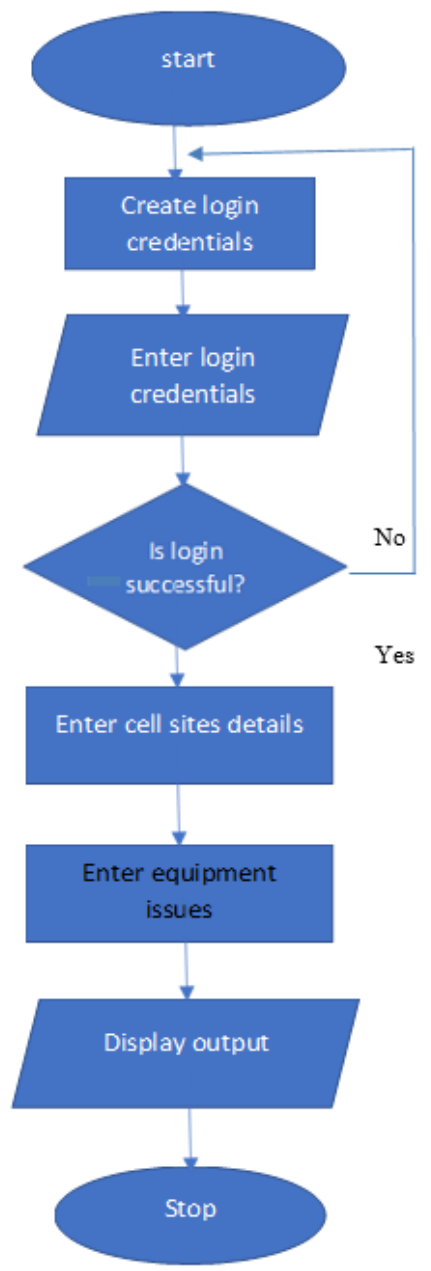

\section{Database field names}

TABLE 1: DATABASE TABLE SHOWING ALL THE FIELD NAMES DECLARED AND USED IN THE SYSTEM

\begin{tabular}{|l|}
\hline Field Names \\
\hline Siteid \\
\hline Region \\
\hline Omp \\
\hline Location \\
\hline Status \\
\hline Cost \\
\hline Revenue \\
\hline Profit \\
\hline gintegrated \\
\hline Gstatus \\
\hline trafic2g \\
\hline trafic3g \\
\hline tdependent \\
\hline ldependent \\
\hline Type \\
\hline
\end{tabular}

\begin{tabular}{|l|}
\hline Acstatus \\
\hline Atsstatus \\
\hline Aviation \\
\hline earthening \\
\hline gencapacity \\
\hline Genstatus \\
\hline genbatstatus \\
\hline Rectifier \\
\hline Batteries \\
\hline Issues \\
\hline Others \\
\hline Ecgvra \\
\hline Metertype \\
\hline meternumber \\
\hline Guards \\
\hline Comment \\
\hline
\end{tabular}

Fig. 3. Flowchart diagram showing the pictorial diagram of the system and logical flow

\section{E. Database structure}

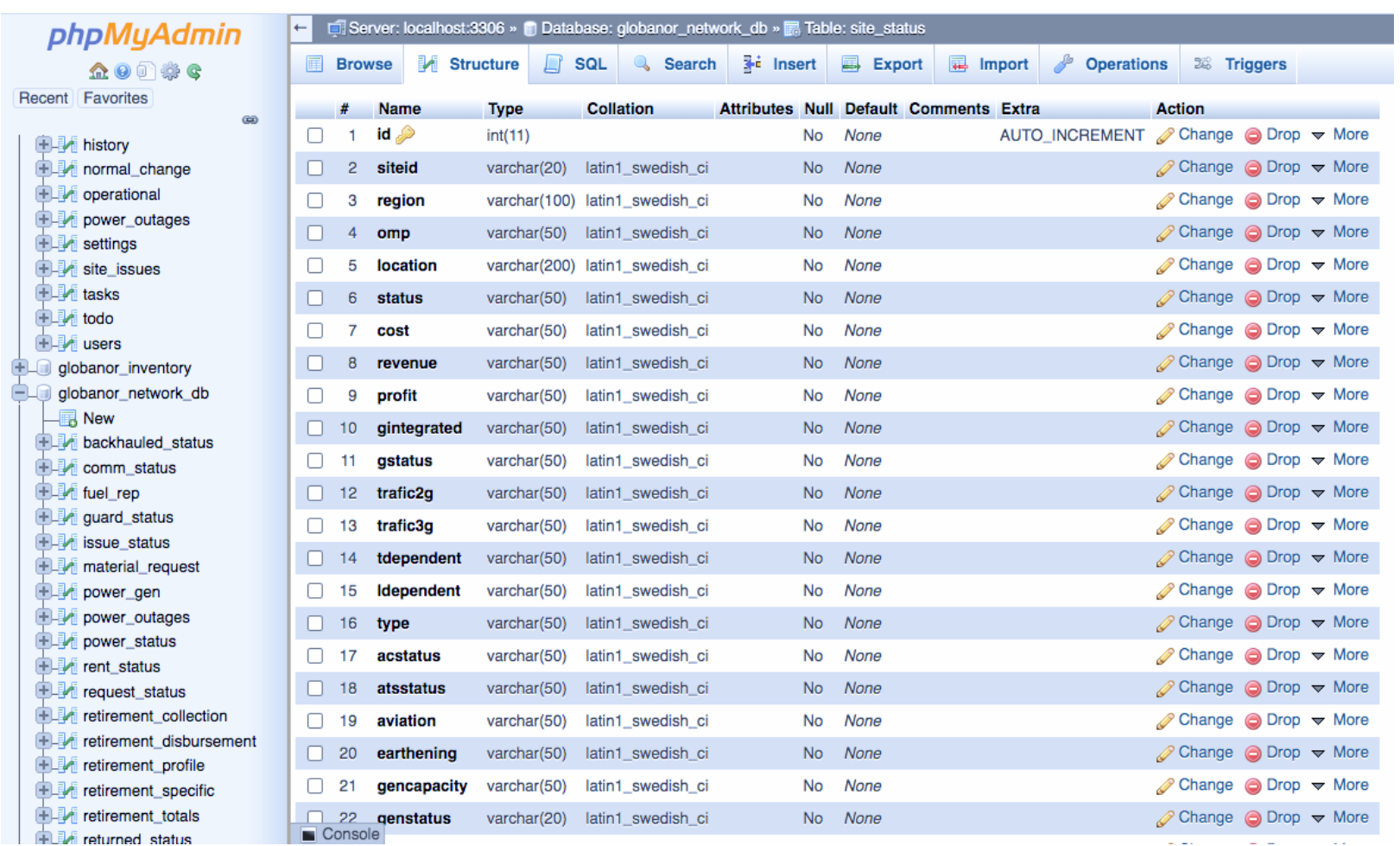

Fig. 4. Database structure of cell sites. 


\section{F. Programming Development Tools}

The automated mobile telecom cell site system was developed with the under listed software development tools:

- following programming tools were used in the development of the system:

- $\mathrm{PHP}$

- HTM

- MySQL

- WAMP
- JavaScript

- Sublime text Editor.

\section{RESULTS}

A. Source codes

The Fig. 5 to 9 show the system sources code that were developed using the above software development tools.

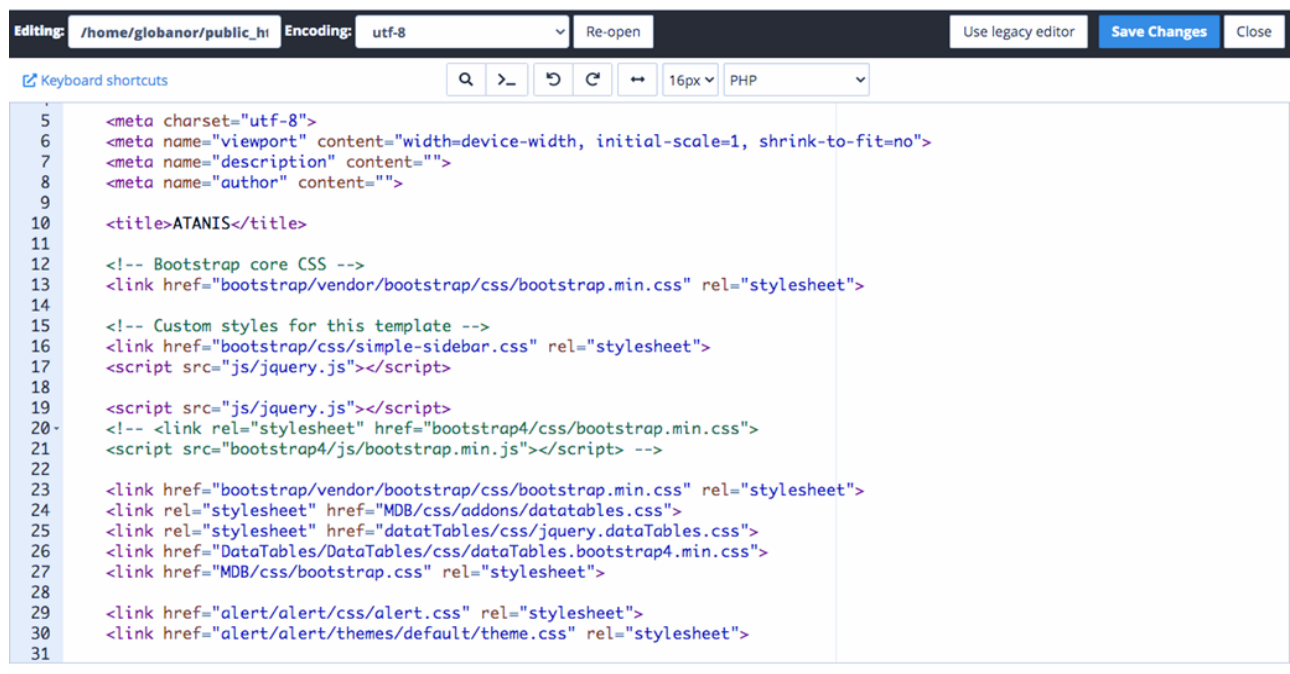

Fig. 5. Source codes.

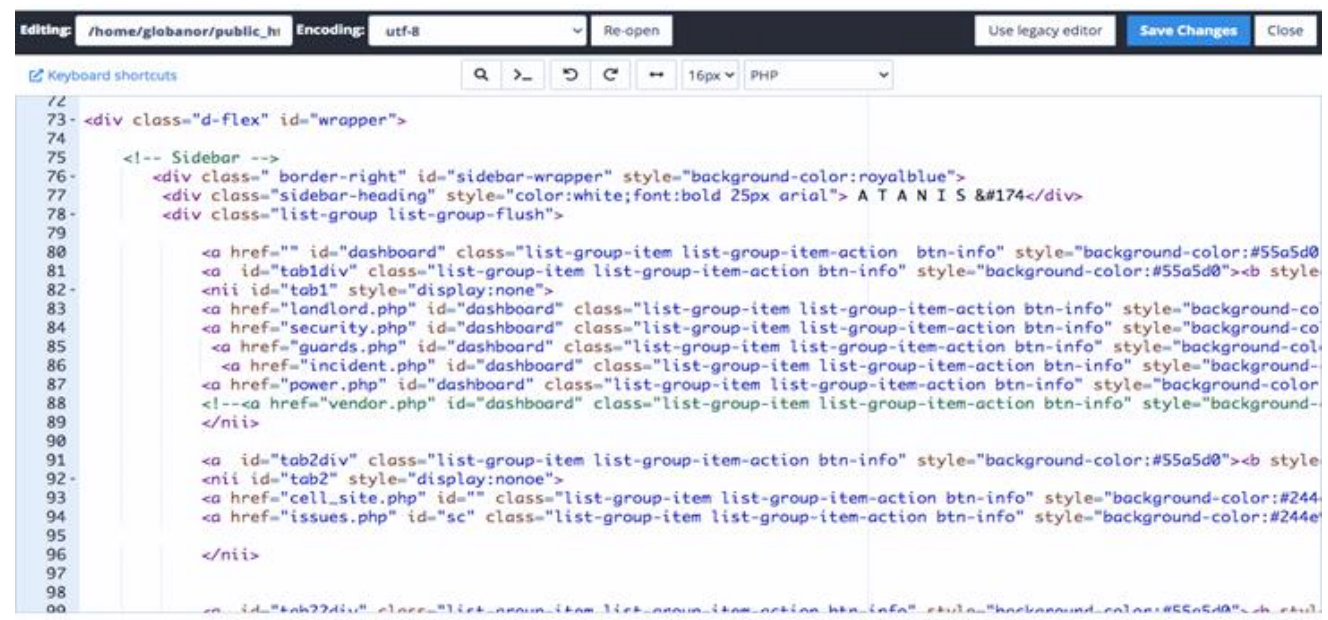

Fig. 6. source codes

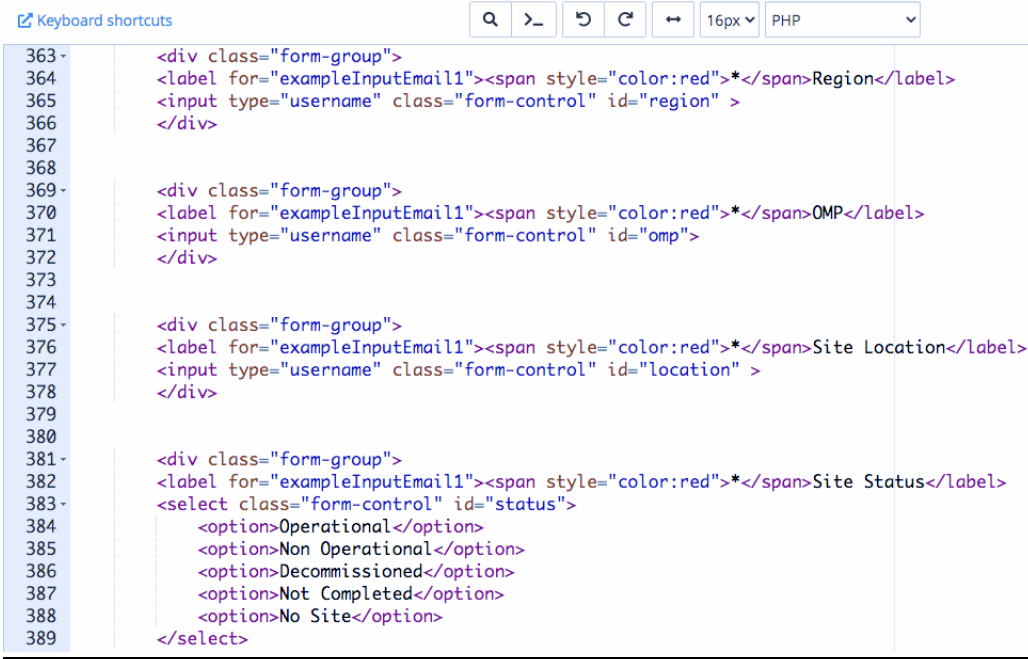

Fig. 7. Source codes, 


\section{B. Cell site status}

Figure 8: It displays cell site information such as site ID, region, contractor, site location, site status, operational cost, profit/loss, revenue, 3G integration, 3G status, $2 \mathrm{G}$ integration, $2 \mathrm{G}$ status, etc.

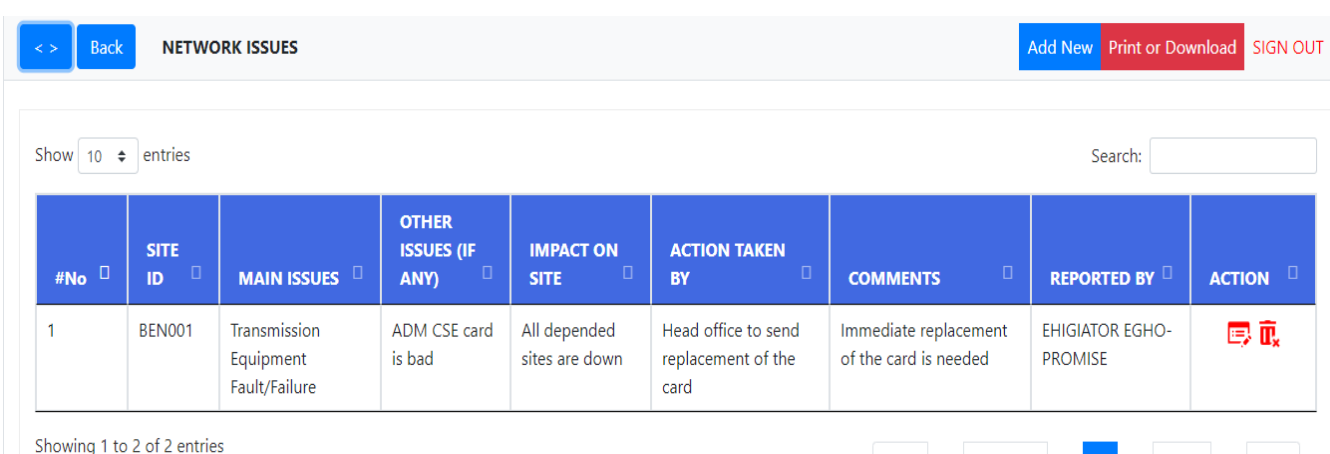

Fig. 8. Network issues interface

\section{Cell site issues}

Figure 9: It displays different problems affecting cell sites equipment and who is responsible for fixing the problems.

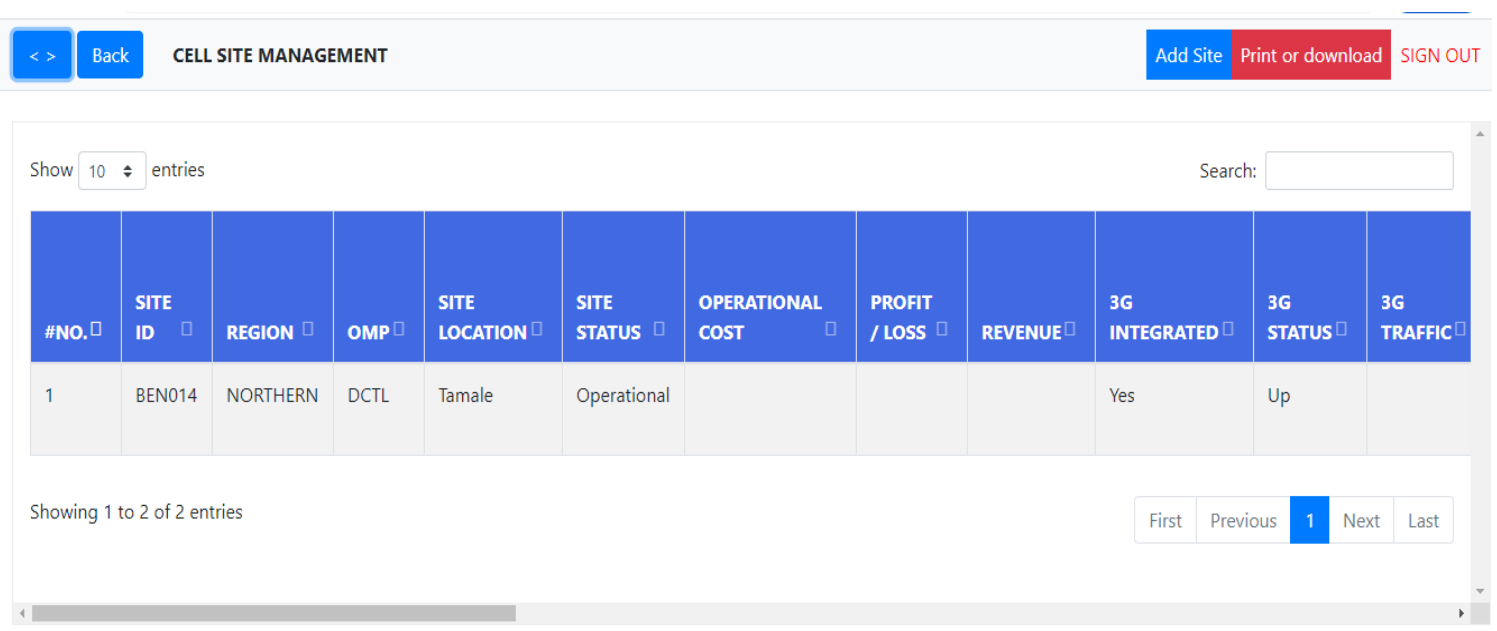

Fig. 9. Cell sites management interface

\section{CONCLUSION AND RECOMMENDATION}

\section{A. Conclusion}

Based on the results above, the automated mobile telecom cell site system has been effectively developed using a reliable software development model. The system provides accurate and reliable online information about the status of equipment at cell sites and determine profit or loss from such sites.

\section{B. Recommendation}

We suggest that the automated mobile telecom cell site system should be implemented by telecom service providers because of its numerous benefits mentioned above. We further recommend that web-based spares management system should be developed to provide early warning of any equipment before it affects services.

\section{REFERENCES}

[1] Egho-Promise, Finu, Kponyo, Amankwah, Adu Mensah (2020, August). E-Telecommunication Information System. International Journal of Research-GRANTHAALAYAH,Vol8(08),403-412.doi: https://doi.org/10.29121/granthaalayah.v8.i8.2020.1181.

[2] Internet solutions (2017, September 13). 5 benefits of effective communication technology in the it department. Retrieved from https://www.is.co.za/blog/articles/5-benefits-of-effectivecommunication-technology-in-the-it-department-tofu/.

[3] Gaille, B. (2018, February 11). 25 Advantages and Disadvantages of Qualitative Research. BrandonGaille Small Business \& Marketing Advice. Retrieved from https://brandongaille.com/25-advantagesdisadvantages-qualitative-research/.

[4] Terry, J. (2020). Benefits of Agile Development. Planview. Retrieved from https://www.planview.com/resources/articles/benefits-of-agiledevelopment/.

[5] Educba (2020). Agile in SDLC. Retrieved from https://www.educba.com/agile-in-sdlc/.

[6] Coll, E.C., Eng, M., Eng, P. (2008). Telecom 101.Canada: Teracom Training Institute Ltd. 


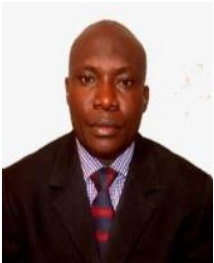

Dr. Egho-Promise Ehigiator Iyobor received his B.Sc. degree in Computer Science from University of Benin, Edo State, Nigeria, in 1998, Higher Tech. Diploma in Electrical/Electronic Engineering from Opencast Polytechnic, Edo State, Nigeria in 1999, MBA degree from Ladoke Akintola University of Technology, Ogbomoso, Nigeria, in 2002, $\mathrm{PhD}$ degree in ICT from The International University, Missouri,

USA in 2012, M.Sc. degree in IT from Sikkim Manipal University, Gangtok, India in 2016 and several other academic and professional certifications. He is a chartered fellow in Chartered Institute of Strategic Managers and Leaders-International. His research interests include Data Communication \& Networking, Telecommunication, Cyber Forensics and Cyber Security. He is currently the regional technical head of Glo Mobile Ghana Limited, Northern Region, Ghana 